\title{
イノベーションを創出する 工学系人材有成に向けて
}

笠木伸英

\section{1. 新世紀の国造り}

表1は、米国工学アカデミーが選んだ、20世 紀の 20 大技術革新のリストである ${ }^{1)}$ 。これらの 技術は、この 100 年間に開発され、多くの人々 が容易に手にすることが出来るほど広く普及し ている。400万年といわれる人類史上、 20 世紀 が科学技術の開発・普及、その結果生じた社会 変化の側面では極めて異例な 100 年であったこ とがわかる。このような 20 世紀における技術の 目覚ましい進展と普及は、災害や事故を防ぎ、 産業を支え、豊かな物資を供給し、病気を克服 し、健康を促進して長寿を可能にしてきた。技 術は、間違いなく社会の要請に応えてきたとい える。新世紀を迎え、人類社会の目標は、肥大 化した人間圈を地球と共生し得る持続的なシス テムとして再構築すると共に、多様な価值観を 有する人々に、健康で快適な生活と安全で安心 な社会を保障することであり、技術と工学の果 たすべき役割は、新たな知の創造と活用を通じ て人類の目標に貢献することといえる。本稿で は、このような新しい時代において活躍が期待 される技術者の姿、そうした技術者を含む工学 系人材育成を担う大学教育のあり方について、 私見を述べてみたい。

我が国は、戦後の困窮の時代を克服して既に 先進国の仲間入りを果たし、その国土の狭さと は裏腹に、世界の政治経済の中で主要なプレゼ ンスを示す位置にある。日本のGDPは約500兆
円で、世界の1割強といわれる。少なくともその 規模と影響力ではトップランナーの仲間入りを 果たしている。一方、我が国の人口は昨年末で1 億 2,800 万人弱、人口統計史上初めて減少に向 かい始め、2050年には1億人程度となると予想 されている。産業を支える生産年齢人口（15～ 64歳) は戦後一貫して増加を続けたが、1995年 の 8,700 万人のピーク後、 2030 年には7,000万人 弱、 2050 年には 5,400 万人弱（現在より 15 ポイ ント低い、対人口比 $53 \%$ 程度）と予想される。 こうした急速な人口減少は、世代間負担の不均 衡など、新たな課題を生む。労働人口が毎年 $0.5 \%$ 減少する中で、生産性の向上が求められる が、そのためには技術革新、そして女性や外国 人を含め優れた人材の確保が鍵となる。

とはいえ、経済規模だけが国際的に尊敬を集 める要素ではないから、縮小社会にも明るい夢 を描くことが可能である。狭い国土は広くなり、 環境負荷低減に有利なはずである。技術におけ る我が国の活躍は、すでに優れた工業製品を世

\section{表 1 20世紀の20大技術革新 (米国工学アカデミーによる)}

1. 電力 . 電化

2. 自動車

3. 航空機

4. 上下水道

5. 電子技術

6. ラジオ・テレビ

7. 農業機械化

8. コンピュータ

9. 電話 $\cdot$ 通信

10. 空調 · 冷凍
11. 高速道路

12. 宇宙船

13.インターネット

14. 画像技術

15. 家庭用電化製品

16. 医療健康技術

17. 石油. 石油化学

18. レーザー・光ファイバ一技術 19. 原子力技術

20. 高性能. 高機能材料 
界に供給してきた実績に裏付けられており、日 本製品の省物資、省エネルギー、安全性、高品 質・低コストなど、優位性は世界に比類無い。 今後は、さらに節約技術、循環技術、文化融合 技術など、日本独特の価値観と感性に根ざした 技術 $^{2)}$ にも期待がかかる。日本の伝統文化や環 境との調和を重視する思潮が、世界の多くの 人々の共感を得ていると聞くことも多い。

つまり、新世紀の我が国においては、イノべ ーションを通じて、今後他国でも予想される人 口減少、高齢化の課題を我が国が率先して克服 し、豊かな社会を造る模範を示すことが求めら れているといえるだろう。こうした時代に鍵と なる役割を果たすのが、技術者を含む専門職業 人の存在である。

\section{2. 国を支える専門職業人 としての技術者}

21世紀の我々が生きる知識基盤社会では、政 治、経済、産業、国土、交通、医療、教育、科 学など、様々な社会システムをよりスリムで機 能的に創造し、これら高度複雑化したシステム を健全に運用、経営する人材としての多様な専 門職業人 ${ }^{1}$ が必要である。図 1 は筆者の考える社 会と専門職の関係である。様々な専門職が自律 性を持って社会に認知される中で、それぞれの 専門職には、基礎科学として知識の体系を形成 する役割を有する者から、市民へ具体的なサー ビスを提供する臨床的な役割を果たす者まで分 布している。例えば、大学人は教育者であると 同時に、多くの場合研究者でもあ るし、工学系では技術者としての 役割も有する。個人は複数の職業 人としての役割を担うことにもな る。

技術者は、社会の活力を生み、 人にゆとりを与えるための、高度 な科学技術専門知識と豊富な経験 を有する専門職業人として位置付 けられる ${ }^{3)}$ 。技術系人材育成は海外 でも主要目標となっているが、第3 期科学技術基本計画でも「モノ」よ り「人」をより重視する方向性が強 調されている。技術系学協会、日 本技術者教育認定機構、経団連に おいても、新時代に相応しい人材 
方成の具体的方法について熱心な議論が継続し ている。そこには、少子高齢化と理工系離れに よる技術者の “数の問題”と、新時代のイノベ ーションを可能とする人材の “質の問題”が存 在する。

日本の高等工学教育を経た技術者人口は、約 250 万人といわれる。その中には、約 40 万人の 工学研究者、 5.6 万人の技術士が含まれる。每年 11 万人の理工系の卒業生が輩出されるが、その うち大学院は3割に達しているという。今後も大 学院進学率は増加する傾向にあるものの、少子 化と若者の理工系離机により加速する技術者人 口の減少が危惧される。その理由の一つは、技 術者に対して、努力に見合った十分な社会的評 価が与えられていないという事情である。一見 難しそうな数学や理科を要し、㛜しい競争に曝 されながら相応に報われない资に映る技術者像 が、若者にとって自分の人生の有力な選択肢と なりにくいことは容易に想像がつく。欧米諸国 でも、医師、并護士、事業家などに比べて技術 者の社会的地位は高いとは言えないが、国造り において技術が中核的な役割を果たす我が国で は、この問題は特に深刻である。

他方、工学教育の “質の問題” は、新世紀の グローバル社会に拉ける技術者に求められる資 質の変化に起因している。すなわち、現代の技 術者には、俯瞰的な視野や自らの仕事の位置付 けを理解する力、そして專門知識を使いこなし てプロジェクトを遂行するためのマネージメン 卜力、チームワーキング力、リーダーシップな どを含む、技術者としてのコンピテンシーとも

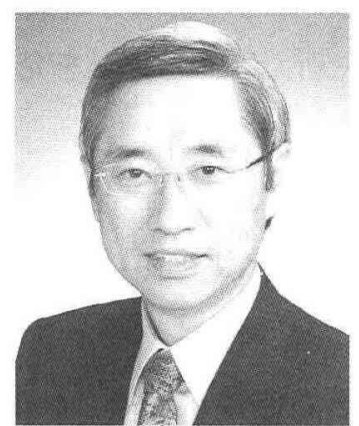

PROFIIS

笠木伸英

（かさぎのぶひで 1947年生）

日本学術会議第三部会員、東京 大学教授、王立スウェーデン科 学アカデミー会員、日本機械学 会会長

専門：熱流体工学、エネルギー システム工学
いえる能力が明示的に求められている。こうし た要請に応えるため、専門知識やスキルの教育 に留まらず、社会・経済・環境に関わる文脈の 中で形成される、21世紀型の工学教育プログラ ムの構築が望まれている。

\section{3. イノベーション創出人材と教育改革}

そもそも、科学技術的な価值を社会経済的な 価値に還元するイノベーションを可能とする資 質は、どのように㕕成されるのであろうか。初 等教育での体験も重要である。絵を描く、作文 を書く、工作をする、こういった自己表現の喜 びを、子供の頃から学校でも、家庭でも十分味 あわせたいものである。また、多くの人との接 点から自他の特質を体験的に理解させ、自己の 存在に自信と誇りを持たせ、他者を認める力を 養う必要がある。筆者らの少年時代は、エジソ ンに憧机る好奇心旺盛な子供は多かったし、不 用となったボール紙や木の箱は最高の遊び道具 であった。材料を手に、これを使って何が作れ るか、胸をときめかしたものである。小学時代 は、ものづくり型の遊びや教育がものづくりだ けでなく、計画力や実行力などの獲得に効果的 という調查結果もある ${ }^{4)}$ 。幼少期のそのような 
体験が、創造性や新たなものごとを発想し提案 する勇気を涵養すると言える。

さて、視点を変えて、大学における人材育成 のあり方について考えてみたい。イノベーショ ンという観点が大学教育にも必要とされており、 産業界からも大きな期待が寄せられているが、 教育現場での捉え方は一様ではない。そのため、 教員の多くに総論的には理解されているが、具 体的な話となると意見の分布は大きい。従って、 現在まず必要とされることは、少なくとも専 攻・学科ごとに教員が教育の理念と目標をきめ 細かく設定かつ共有して、それらを教育カリキ
ユラムによって具現化することである。つまり、 組織として人材を育成する体制と運営を実現す る必要がある。

進学率の増加した大学院教育の改革は喫緊の 課題といえる。大学院教育の本質は、講義演習 の体系の中で養われる専門知識と応用力、そし て未踏分野にチャレンジする様々な研究活動の 中で養わ机る計画力、実践力、マネージメント 力などを付与することである。知の創造の観点 からは、ものづくりを追いかけた経験知・解明 知から、ものづくりを創造する先導知を目指さ ねばならない。そのためには具体的な出口を意

\section{表2 大学院教育に関する意識比較}

\begin{tabular}{|c|c|c|}
\hline & 大学院前期（修士）課程 & 大学院後期（博士）課程 \\
\hline $\begin{array}{l}\text { 企業技術者 } \\
\text { の評価 }\end{array}$ & $\begin{array}{l}\text { • 基礎学力が不十分、大学の出口管理が } \\
\text { 不足。 } \\
\text { ・問題設定解決能力や創造力など、もの } \\
\text { づくりの力に欠ける。 } \\
\text { •コミュニケーションカ、チームワーキ } \\
\text { ングカなど、技術者として必要な力が } \\
\text { 育成されていない。 }\end{array}$ & $\begin{array}{l}\text { • 専門知識の幅が狭く、可塑性、柔軟性に欠 } \\
\text { ける。 } \\
\text { ・プロジェクトマネージメントなどの経験が } \\
\text { 不足で、指導力が期待できない。 } \\
\text { •MOT、知財、企業経営など、幅広い理解 } \\
\text { 力が不足。 } \\
\text { ・研究室毎に、人材育成の達成度に差がある。 }\end{array}$ \\
\hline $\begin{array}{l}\text { 大学教員 } \\
\text { の認識 }\end{array}$ & $\begin{array}{l}\text { • 企業の修士採用意欲は旺盛で、就職活 } \\
\text { 動が大学院教育を歪めている。優秀な } \\
\text { 学生が修士で引き抜かれる。 } \\
\text { • 学生にもっと勉強をさせたいが、厳し } \\
\text { い指導は学生に嫌われる。 } \\
\text { •学生に、自立し、人間関係を築く力が } \\
\text { 不足している。 }\end{array}$ & $\begin{array}{l}\text { ・博士進学者の減少が、大学の研究戦力低下、 } \\
\text { 国の競争力低下を招くことを危惧。 } \\
\text { ・博士課程修了者、あるいはポスドクの企業 } \\
\text { 採用は不活発で、修了後のキャリアパスが } \\
\text { 見えない。 } \\
\text { •企業における博士人材の処遇、活用が不十分。 }\end{array}$ \\
\hline 学生の意識 & $\begin{array}{l}\text { ・修士課程で学部時代の勉強不足を補い } \\
\text { たい、もう少し大学にいたい。 } \\
\text { •知識が多少不足しても、入社後OJTで } \\
\text { 補っていける。 } \\
\text { •修士で就職したほうが、選択の幅が広 } \\
\text { <、希望の企業に入りやすい。 }\end{array}$ & $\begin{array}{l}\text { ・博士課程では経済的自立ができず、社会に } \\
\text { 独立した大人として認められない。 } \\
\text { ・博士の学位を取っても評価されず、企業に } \\
\text { 就職する場合、修士に対して優位性がない。 } \\
\text { ・企業の方針で研究テーマが決められ、自ら } \\
\text { 設定できない。納得いくまで研究を続けら } \\
\text { れない。 }\end{array}$ \\
\hline
\end{tabular}


識したパスッール型研究 ${ }^{5)}$ の推進が必要であり、 そのような場での若者の鍛鍊が重要である。ま た、学部との関係では、学部は技術者としての 基礎固め、つまりPre-engineering、大学院は Professional SchoolあるいはResearch School と明確に位置付け、それぞれの教育目標を設定 すべきであろう。さらに、相互の役割分担の理 解を共有する、息の長い産学連携は、社会知識 の付与によって大学を強化し、また、そのよう な環境で育つ人材が産業界でも教育研究機関で も未来の牽引力として期待される。

ここで、最近の試みとして、筆者の関係する 東京大学 $21 \mathrm{COE}$ 「機械システム・イノベーシ ヨン」を紹介したい。当該 $21 \mathrm{COE}$ では、学部か らの進学率がすでに $85 \%$ となった大学院教育の 改革に取り組んでいる。一昨年以来、関連企業 十数社からの参画を得て懇談会を設置し、具体 的かつ可能な改革について継続的に検討してき た。この会の特徴は、当事者である大学院生も 含めて議論を進めたことである。表 2 は、懇談会 で表明された産学そして大学院生の意識や見解 であり、まずは相互の理解こそが必要であるこ とが浮き彫りになった。

これらから見え隠れする問題は、大学の努力 だけで解決できるわけではないが、以下のよう な改革が取り組まれることとなった。

“各専攻の修士・博士課程での人材育成の理 念と教育の達成目標（育成されるべき人材像） を改めて明示し、それらをカリキュラムに具 現化する。そして、習得すべき資質や能力が、
どの講義、演習、実験などにおいて養われる のか関連づけて、学生に明示する。産官学界 に扔いて、専門的研究・開発・経営能力を発 揮できる国際的人材の育成を共通理念に置く。 博士課程においては、学生個々人の俯瞰的視 野、国際環境でのリテラシー、そして研究 者・技術者としてのコンピテンシー（個性的 競争力）の涵養を目指す。学生が、専門分野 のみに偏ることなく、幅広い専門知識を習得 し、自らの研究領域以外の研究 - 技術動向に 対する理解力も獲得できるようにする。また、 指導教員以外の研究者や技術者の姿勢や価值 観に触れる機会を導入し、さらに組織として 教育の質を保証する仕組みを構築する。”

加えて、次のような具体的な方策案も検討さ れている。

- 修了要件の取得単位数、その内訳としての講 義、演習、論文などの配分を見直す。

・提供科目を分野別にグループ化して、そのう ちの一つを主分野とし、それ以外の分野から も必要数の単位取得を義務づける。なお、科 学技術英語、技術倫理、技術経営などの履修 を求める。また、科目の履修においては、関 連基礎科目の習得を履修条件とする。

- 専攻横断型のカリキュラム (調査研究、研究 発表、輪講など）を提供し、研究室や専攻を 超えた学生の研究交流やチームワーキングの 機会を与える。

- 主指導教員、そして専門分野の異なる副指導 教員の複数による研究指導制度を可能とする。 
・博士課程学生を研究アシスタント（RA）とし て積極的に登用し、その役割を責任をもって 果たさせることによって、指導力習得と共に 人格的成長を促す。

・学生の国際経験を促すため、国際会議発表, 短期留学などを資金的援助と共に奨励する。 国際リテラシー、コミュニケーション力強化 のためのコース提供やトレーニング支援を行 う。

・産業界、他研究機関でのインターンシップや 流動研究員などを奨励する。

このような大学教育の改革がイノベーション創 出に繋がるのであろうか、その答えを得るには 時間を要しそうだ。

イノベーションは、基礎研究による発見・発 明から、技術シーズの有成、資本投入、製品開 発、市場の開拓、規制の緩和、普及、サービス など様々な過程が繋がって初めて可能となる。 実際、死の谷、ダーウィンの海とよばれるイノ ベーションの障壁を越えるためには、経済指標 で計られない時間と資本の投入や、規制緩和も 必要な場合もある。欧米諸国で、国家目標とし ての防衛、宇宙開発などで開発された大型技術 が民生技術に転用された例は、半導体、航空工 ンジンなどいくつもある(6)。また、新技術シー ズが知られてからも、それが製品として市場に 導入されるまで、生産技術や品質管理技術にブ レークスルーが達成されるまで、長い時間がか かった例も少なくない。一方、技術としては優 れていても、ユーザーにとって過剩技術であっ たり、市場の成熟度とのミスマッチもあり得る
ので、技術者だけの問題ではないことは明らか である。また、全ての開発過程に目利きでき、 すぐにでもべンチャーを始められる人材を大学 で専ら育てるということは幻想であり、むしろ 技術者のキャリアパスから見れば、年齢と共に 経験を経て異なる役割を担うことが自然であろ う。従って、イノベーションのプロセスを理解 し、研究、開発現場でもそれらを意識しつつ、 自分の仕事の位置付けを見いだす力が重要であ ろう。また、知識体系、製品開発過程、生産技 術、市場など、研究開発のどのような既存条件 も、それを疑ってみる勇気がなけ机ばイノベー ションには繋がらない。そのような資質をどの ように育てるのかについても、専門分野を越え て継続的な吟味が必要である。

\section{4. むすび}

新世紀の我が国で必要とされる工学系人材育 成のあり方、そして、国造りや人材育成のビジ ョンを共有する、具体的目標を明示した教育プ ログラムへの組織的な取り組みの必要性につい て述べた。ここで、社会の側での技術者育成と 大学に打ける工学教育との、相互連携の重要性 を再度指摘して打きたい。

すなわち、工学教育を通じて優れた人材が社 会に供給されるためには、まず教育機関は学生 に教育課程の達成目標を明示・約束し、学ぶ者 と教える者との協働を促すことが肝要である。 他方、社会（産業界）は、工学教育の先に位置 する専門職としてのキャリアパスを示し、学ぶ 者にインセンティブを与え、技術者に誇りと自 
信を回復させる努力を急ぐべきである。このよ うに、大学と社会とが相互に連携して活動する ことで、初めて新世紀において必要とされる人 材の育成が図られる。大学教育改革については これまでも熱心に行われてきたが、その成果が 十分でなかった一つの原因は、改革の議論が教 員だけで行われてきたことであろう。今後は、 産業界、そして学生の参加を得て、全てのステ ークホルダーがビジョンと目標に対する理解を 共有しつつ、同じの高さの目線でオープンに、 継続的な議論を続けられるかどうかが鍵と言え る。大学の内なる議論のみならず、開かれた議 論の場を目指すべきである。

最後に、技術革新そして人材育成の両者にお いて、クローズド・イノベーションからオープ ン・イノベーション への方向転換を挙げたい。 1970年代の米国大企業は自らの基礎研究部門で シーズを生みだし、その製品化までの一連の研 究開発プロセスを組織内で達成していた。しか し、組織内の知のストックが増すにつれ、それ らは人と共に流出して、1990年代には組織の外 に多くのイノベーションを創出する結果となっ た。つまり、組織内の垂直統合型リニアモデル から、水平分業ネットワーク型モデルへと変わ っていったのである。このようなオープン・イ ノベーションやオープン・アライアンスが、今 後の改革のヒントとなり得るのではないだろう か。イノベーションの長い道程を越えるために は、様々な条件が揃わねばならない。そのため、 教育機関で言えば研究室、学科専攻、大学を、 産業でいえば部署、企業、業界を超えて協働し
てこそ、人材を育て、新技術を創出することが 可能となろう。特に、人材育成においては、多 くの人と価值観との出会いを可能とする柔軟な 組織や資源分配の制度が幅広く導入される必要 もあることも指摘しておきたい。
参老文献

1. National Academy of Engineering, "Greatest Engineering Achievements of the 20th Century," http://www.nae.edu/.

2. 月尾嘉男、縮小文明の展望 千年の彼方を目 指して、東京大学出版会、2003.

3. 大橋秀雄、これからの技術者、オーム社、 2005.

4. 山田康作、子どもの発達とものづくり教育、 日本産業技術教育学会誌46-1、2004, pp. 51-54.

5. D. E. Stokes, "Pasteur's Quadrant: Basic Science and Technological Innovation," Brookings Institution Press, 1997.

6. 中山恒、技術予測論、日科技連、 1998 .

7. H. Chesbrough (大前訳)、Open Innovation、産業能率大学出版部、2004. 